\title{
Spontaneous peripheral chorioretinal neovascularisation in association with sickle cell anaemia
}

\author{
JAMES C. LIANG AND LEE M. JAMPOL \\ From the Univeristy of Illinois Eye and Ear Infirmary, 1855 W. Taylor Street, Chicago, Illinois 60612, USA
}

SUMMARY Chorioretinal neovascularisation was noted in the midperipheral fundus of a young black girl with sickle cell anaemia. Rapid-sequence fluorescein angiography showed choroidally fed neovascularisation in the centre of a large black sunburst (chorioretinal scar). We suspect that a massive midperipheral retinal haemorrhage from the sickle cell disease caused the sunburst and altered Bruch's membrane, thus allowing the ingrowth of choroidally fed vessels.

Peripheral retinal neovascularisation is a well described finding in patients with haemoglobin SC disease, sickle cell $\beta$-thalassaemia, and homozygous sickle cell anaemia. ${ }^{12}$ Peripheral chorioretinal and choriovitreal neovascularisation has been reported to occur following argon laser or xenon arc photocoagulation for proliferative sickle cell $^{3-5}$ and diabetic retinopathies. $^{6-8}$ To our knowledge such neovascularisation has not been noted to occur spontaneously in either of these conditions. We report a case of spontaneous chorioretinal neovascularisation in association with sickle cell anaemia in the peripheral fundus of a 14-year-old girl.

\section{Case report}

A 14-year-old black girl with sickle cell anaemia was referred to the Sickle Cell Eye Clinic at the University of Illinois Eye and Ear Infirmary for a routine eye examination. She had no ocular complaints and denied previous visual difficulties. There was no history of ocular trauma, surgery, or photocoagulation.

The best corrected visual acuity with a minor hyperopic correction was 20/25 (6/7.5) OU. Results of external, ocular motility, and slit-lamp examinations were normal except for $3+$ conjunctival sickling signs bilaterally.

The maculas and discs appeared normal bilaterally.

Correspondence to Dr James C. Liang, Department of Ophthalmology, University of Southern California, Estelle Doheny Eye Foundation Building, 1355 San Pablo Street, Los Angeles, CA 90033, USA.
The right fundus had multiple black sunbursts (peripheral chorioretinal scars) from one-half to 2 disc diameters in size located at the $3,4,5$, and 6 o'clock equators. In the left eye black sunbursts from one-half to 2 disc diameters in size were at the 7, 8, 9, and 11 o'clock equators. In addition a very large 6 by 7 disc diameter black sunburst was located just posterior to the equator from the 3 to 5 o'clock meridians (Fig. 1) with a one-half by one disc diameter patch of fibrous tissue in its centre.

No obvious areas of retinal neovascularisation were apparent with indirect ophthalmoscopy. However, rapid-sequence fluorescein angiography showed choroidally fed neovascularisation in the fibrous tissue at the 4 o'clock position in the large black sunburst of the left eye (Figs. 2, 3, 4).

Blood tests gave the following results: haemoglobin, $10 \cdot 1 \mathrm{~g} / \mathrm{dl}$; haematocrit, $27.9 \%$; white blood cell count, 8.9 $\times 10^{9} / 1$. A quantitative haemoglobin electrophoresis showed $\mathrm{S}$ haemoglobin $88.8 \% ; \mathrm{A}_{2}$ haemoglobin $3.9 \%$, and fetal haemoglobin $7 \cdot 3 \%$. The irreversible sickle cell count was 5.9\%.

The patient has been followed up for more than a year; there has been no change in the area of neovascularisation. No photocoagulation or other therapy has been attempted because of the stability of the lesion and the disappointing results previously described following treatment of this type of neovascularisation. ${ }^{45}$

\section{Discussion}

Spontaneous peripheral chorioretinal neovascular- 


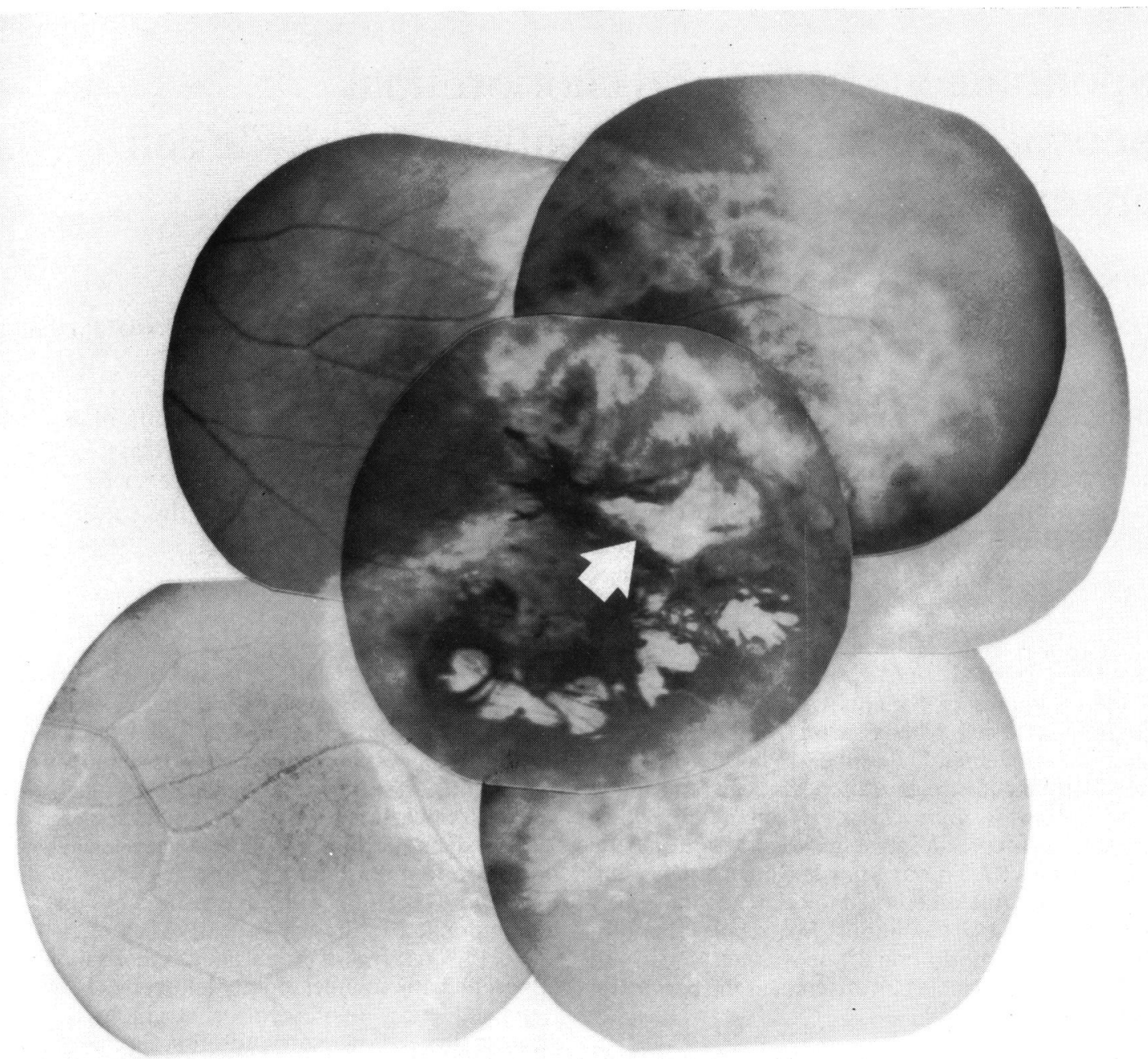

Fig. 1 Fundus photograph showing the very large black sunburst in the temporal periphery of the retina of the left eye. The arrow indicates a tuft of fibrous neovascularisation.

isation is a rare finding in patients with sickle cell eye disease. It has not been previously noted clinically in the more than 1000 patients studied at the Sickle Cell Eye Clinic of the University of Illinois Eye and Ear Infirmary. However, peripheral, choroidally fed neovascularisation is a common complication of intense focal photocoagulation in patients with sickle cell disease. $^{3-5}$ Photocoagulation-induced breaks in Bruch's membrane, together with retinal ischaemia, choroidal ischaemia, and perhaps inflammation, may predispose to ingrowth of choroidal neovascularisation into the retina (chorioretinal neovascularisation) or the vitreous (choriovitreal neovascularisation).
Asdourian and colleagues ${ }^{9}$ have convincingly shown that black sunbursts evolve after occlusion of midperipheral retinal arterioles by plugs of sickled erythrocytes. Ischaemic necrosis of the vessel wall ensues, which in turn can result in intraretinal or preretinal haemorrhage. If the blood dissects to the level of the retinal pigment epithelium (RPE), it may stimulate proliferation and migration of the RPE, which forms a black sunburst. Black sunbursts may be seen in patients with sickle cell anaemia, haemoglobin $\mathrm{SC}$ disease, or sickle cell $\beta$-thalassaemia.

In our patient we suspect that a massive intraretinal and subretinal haemorrhage occurred with resultant 


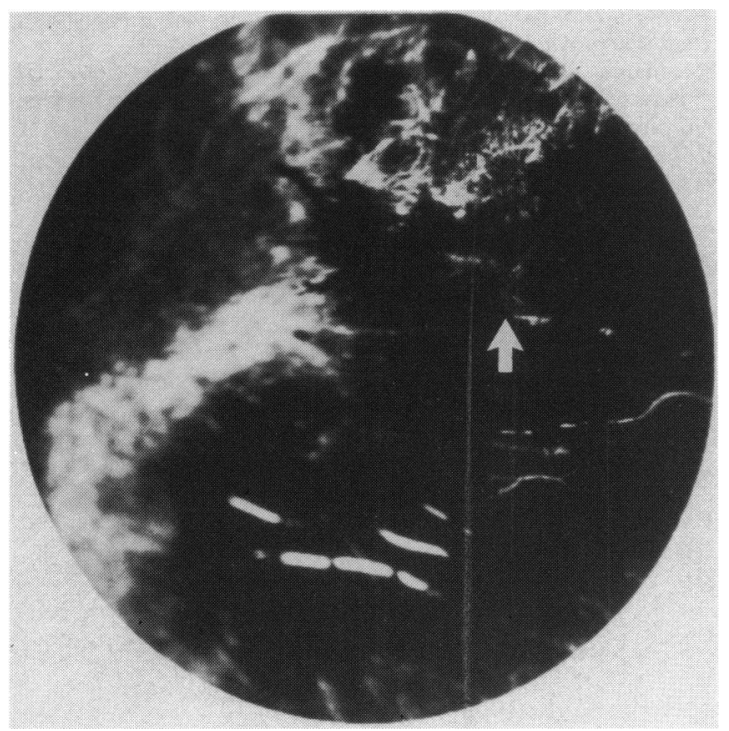

Fig. 2 Early-phase fluorescein angiogram showing filling of the fibrous neovascularisation (arrow) from the choroidal circulation prior to filling of nearby retinal vessels.

formation of a huge black sunburst. We suggest that mechanical factors or the cellular response to the large intraretinal or subretinal haemorrhage altered the extracellular matrix or fibrous component of Bruch's membrane in some way, and that this altered

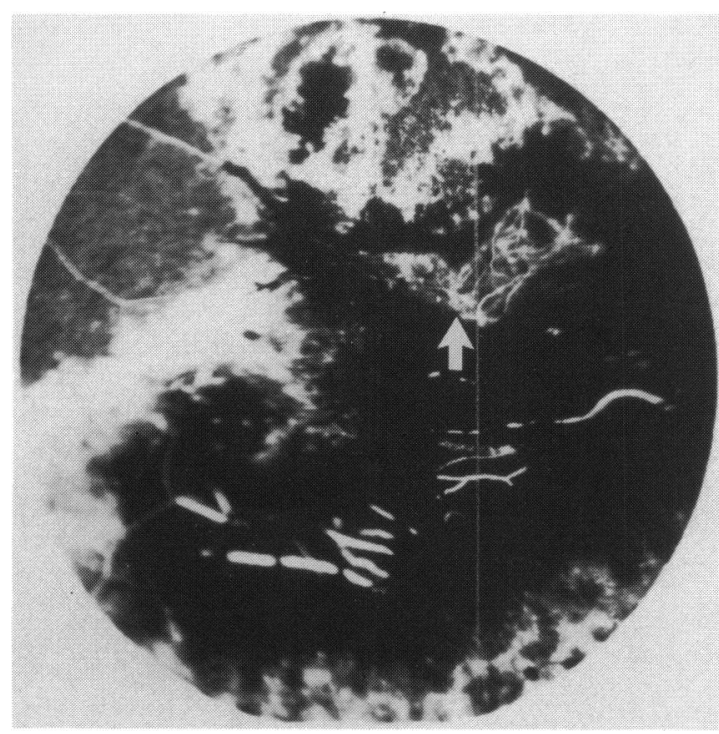

Fig. 3 Later-phase fluorescein angiogram showing filling of nearby retinal vessels. There is no vascular connection between the retinal circulation and the area of neovascularisation (arrow).

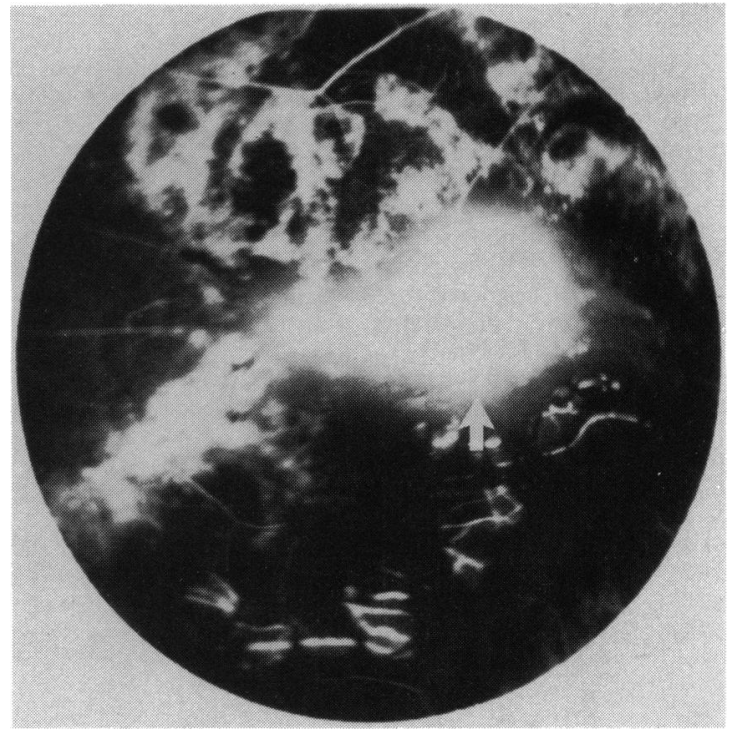

Fig. 4 Late-phase fluorescein angiogram showing leakage from the area of neovascularisation (arrow).

Bruch's membrane, allowing the development of spontaneous chorioretinal neovascularisation.

Choroidal ischaemia following focal photocoagulation was noted in 13 of 19 patients with sickling haemoglobinopathies who subsequently developed choroidally fed neovascularisation. Choroidal occlusive disease in sickling haemoglobinopathies has been described following posterior ciliary artery occlusions. ${ }^{10}{ }^{11}$ Characteristic wedge-shaped or triangular sectors of yellow-brown pigment mottling are seen, ${ }^{11-13}$ but focal occlusions of choroidal precapillary arterioles (Elschnig's spots) or capillaries have not been described. In our patient fundus findings, as well as any fluorescein angiographic indications of choroidal occlusive disease, were absent.

Two recent reports ${ }^{45}$ of choroidally fed neovascularisation following feeder vessel photocoagulation of proliferative sickle cell disease suggest that these new vessels are best left untreated unless absolutely necessary. At the University of Illinois ${ }^{4} 6$ of 7 treated eyes were unchanged or worse following xenon, argon, or cryopexy treatment of choroidally fed neovascularisation. At the University of the West Indies 7 of 11 eyes were unchanged or worse following xenon or cryopexy treatment of choroidally fed new vessels. In our patient the lesion is apparently stable, and no treatment is contemplated at present.

The study was supported in part by Core Grant EY 01792 from the National Eye Institute and Research Grant PHS HL 15168 from the National Heart, Lung, and Blood Institute, Bethesda, Maryland. 


\section{References}

1 Nagpal KC, Goldberg MF, Rabb MF. Ocular manifestations of sickle hemoglobinopathies. Surv Ophthalmol 1977; 21: 391-411.

2 Condon PI, Serjeant GR. Ocular findings in homozygous sickle cell anemia in Jamaica. Am J Ophthalmol 1972; 73: 533-43.

3 Galinos SO, Asdourian GK, Woolf MB, Goldberg MF, Busse BJ. Choroido-vitreal neovascularization after argon laser photocoagulation. Arch Ophthalmol 1975; 93: 524-30.

4 Dizon-Moore RV, Jampol LM, Goldberg MF. Chorioretinal and choriovitreal neovascularization. Their presence after photocoagulation of proliferative sickle cell retinopathy. Arch Ophthalmol 1981;99: 842-9.

5 Condon PI, Jampol LM, Ford SM, Serjeant GR. Choroidal neovascularisation induced by photocoagulation in sickle cell disease. Br J Ophthalmol 1981; 65: 192-7.

6 Galinos SO, McMeel JW, Trempe CL, Schepens CL. Chorioretinal anastomoses after argon laser photocoagulation. Am J Ophthalmol 1976; 82: 241-5.

7 Benson WE, Townsend RE, Pheasant TR. Choriovitreal and subretinal proliferations: Complications of photocoagulation. Ophthalmology 1979; 86: 283-9.

8 Kodama Y, Ishikawa Y, Nomura T, Taniguchi Y. Choroidal neovascularization in the photocoagulated retina with diabetic retinopathy: a light and electron microscopic study. Jpn $J$ Ophthalmol 1980; 24: 35-47.

9 Asdourian G, Nagpal KC, Goldbaum M, Patrianakos D, Goldberg MF, Rabb M. Evolution of the retinal black sunburst in sickling hemoglobinopathies. Br J Ophthalmol 1975; 59: 710-6.

10 Goldbaum MH, Galinos SO, Apple D, et al. Acute choroidal ischemia as a complication of photocoagulation. Arch Ophthalmol 1976; 94: 1025-35.

11 Dizon RV, Jampol LM, Goldberg MF, Juarez C. Choroidal occlusive disease in sickle cell hemoglobinopathies. Surv Ophthalmol 1979; 23: 297-306.

12 Condon PI, Serjeant GR, Ikeda H. Unusual chorioretinal degeneration in sickle cell disease: possible sequelae of posterior ciliary vessel occlusion. Br J Ophthalmol 1973; 57: 81-8.

13 Hayreh SS, Baines JAB. Occlusion of the posterior ciliary artery. II. Chorio-retinal lesions. Br J Ophthalmol 1972; 56: 736-53. 